\title{
Genotypic Correlation Coefficients among Growth, Yield and Quality Parameters in Bathua genotypes (Chenopodium album L.)
}

\author{
Basavaraj, C.N. Hanchinamani, H.P. Hadimani, S.J. Imamsaheb* \\ and S.H. Ramanagouda
}

Department of Vegetable Science, K. R. C. College of Horticulture, Arabhavi - 591218 , Karnataka, India

*Corresponding author

\section{A B S T R A C T}

\begin{tabular}{|l|}
\hline K e y w o r d s \\
$\begin{array}{l}\text { Chenopodium album, } \\
\text { Correlation, Coefficients } \\
\text { and genotypes }\end{array}$ \\
\hline Article Info \\
\hline $\begin{array}{l}\text { Accepted: } \\
\text { 04 July } 2018 \\
\text { Available Online: } \\
\text { 10 August } 2018\end{array}$ \\
\hline
\end{tabular}

\section{Keywords}

\section{Introduction}

Bathua (Chenopodium album L.) is an important underutilized leafy vegetable belongs to family Chenopodiaceae with a chromosome number of $2 n=36$.

It is commonly known with different vernacular names viz., Lamb's quarters, Pig weed, Melde, Goose foot and Fat-hen in English; Bathua sag in Hindi; Kaduoma, Chakota, Sakothinasoppu in Kannada; Vastukah in Sanskrit; Chandan betu in Bengali; Parupukkirai, Chakkararthi Greens in Tamil; Pappukura in Telagu (Pandey, 2008). It is native to Europe and extensively distributed

\begin{abstract}
In the present study, foliage yield per plant was significantly and positively correlated with plant height, number of leaves per plant, number of branches per plant, leaf area, stem girth, fresh weight of plant, dry weight of plant, foliage yield per plot, foliage yield per hectare, vitamin-A, vitamin-c, protein content, calcium content, magnesium content, iron content, zinc content at both phenotypic and genotypic level. Yield per plant was also posively and significantly correlated with plant spread E-W only at phenotypic level. positive and significant correlation was found for fresh weight of plant with dry weight of content, calcium content, magnesium content, iron content, zinc content, foliage yield per plant at both phenotypic and genotypic level.
\end{abstract}

in different parts of world viz., West Indies, South America, North America, Africa, Australia, Oceania and India (Pandey, 2008). In India, it is usually found in Upper gangetic plains, Kashmir, Punjab, West Bengal, Kumaon (Uttaranchal), Maharastra, Tamil Nadu, Karnataka and Peninsular India.

The fresh green leaves are highly nutritive and contains moisture (96 g), energy (30 kcal), protein $(3.7 \mathrm{~g})$, fat $(0.4 \mathrm{~g})$, carbohydrate $(2.9$ $\mathrm{g})$, fibre $(2.1 \mathrm{~g})$, ca $(150 \mathrm{mg})$, phosphorus (80 $\mathrm{mg}$ ), vitamin-A (11,300 IU), thiamine (0.01 $\mathrm{mg})$, riboflavin $(0.14 \mathrm{mg})$, niacin $(0.60 \mathrm{mg})$, vitamin-C (35 mg) (Pandey, 2008). It acts as a laxative, anthelmintic for hookworms, 
roundworms, antiphlogistic, antirheumatic, odontalgic and also acts as a blood purifier (Sanwal, 2008).

Correlations arise due to linkage, pleiotropism and developmental genetic interaction. Correlation of quantitative attributes would help in choosing component characters that are positively correlated with yield. To give a better insight of ancillary characters under selection, correlation coefficient analysis is a tool which measures the relationship between two or more variables. In view of the above facts In view of the above facts, the present studies entitled Genotypic Correlation Coefficients among Growth, Yield and Quality parameters in Bathua genotypes (Chenopodium album L.) was undertaken.

\section{Materials and Methods}

The investigation was carried out at Kittur Rani Channamma College of Horticulture, Arabhavi, Belagavi district (Karnataka) during kharif 2017. The details of the experiment, materials used and techniques adopted in present investigation are presented in this chapter. study comprised of twenty four genotypes the details give in Table number1 with three replications. The designed adopted for study is randomized block design. Each treatment or genotype in a replication was represented by a row of 5.00 meter length with 25 plants. All the cultural practices were carried out to manage the crop. The data were recorded on five competitive fertile plants for growth, yield and quality parameters

The data was analysed using INDOSTAT software programme. For the analysis of the data the following statistical methods were employed, namely analysis of variance, genetic parameters viz., genotypic and environmental variance, environmental coefficient of variation (Burton and Devane, 1952) and classified (high/medium/low) as suggested by Sivasubramanian and Madhavamenon (1973).

\section{Results and Discussion}

Correlation studies indicate the degree of inter-relationship of plant characters for improvement of yield as well as important quality parameters in any breeding programme. Hence, understanding of the inter-relationship between foliage yield and yield influencing characters is vital importance because this would facilitates effective selection for simultaneous improvement in one or more yield characters. The intense and direction of association among the characters was measured by simple correlation. In the present investigation both genotypic and phenotypic correlations worked out for foliage yield and its contributing character. In general, genotypic correlation was higher than phenotypic correlations for most of the characters studied. This indicates that the phenotypic expression of correlation is reduced due to the influence of environment.

In the present study, foliage yield per plant was significantly and positively correlated with plant height, number of leaves per plant, number of branches per plant, leaf area, stem girth, fresh weight of plant, dry weight of plant, foliage yield per plot, foliage yield per hectare, vitamin-A, vitamin-c, protein content, calcium content, magnesium content, iron content, zinc content at both phenotypic and genotypic level. Yield per plant was also positively and significantly correlated with plant spread E-W only at phenotypic level. Similar observations were made by Sarker $e t$ al., (2014), Khurana et al., (2013), Ahmmed et al., (2012) for plant height; Sarker et al., (2014), Khurana et al., (2013) for number of leaves per plant; Sharma (2016), Khurana et al., (2013) for number of branches per plant; Sarker et al., (2014), Khurana et al., (2013) for leaf area; Hassan et al., (2013) for fresh 
weight of plant. Hassan et al., (2013) for stem girth; Hassan et al., (2013) for dry weight of plant; Since, these associated characters are in the desirable direction, it indicated that simultaneous selection for these characters would be rewarding in improving the foliage yield. Plant height exhibited highly significant and positive association with number of leaves per plant, number of branches per plant, leaf area, plant spread E-W, fresh weight of plant, dry weight of plant, foliage yield per plot, foliage yield per hectare, vitamin-A content, vitamin-C content, protein content, calcium content, magnesium content, iron content, zinc content, foliage yield per plant at both phenotypic and genotypic level. This indicates plant height is an important trait while selecting high yielding genotypes in bathua. Similar results were also reported by Kujur
(2015), Diwan (2015) for number of leaves per plant, foliage yield per plot; Kujur (2015) for leaf area;

Number of leaves per plant had found significant and positive association with number of branches per plant, leaf area, fresh weight of plant, dry weight of plant, foliage yield per plot, foliage yield per hectare, vitamin-A content, vitamin-C content, protein content, calcium content, magnesium content, iron content, zinc content, foliage yield per plant at both phenotypic and genotypic level. It indicates if more number of leaves per plant it increases total foliage yield. Similar results were also obtained by Hassan et al., (2013) for fresh weight of plant, dry weight of plant; Kujur (2015) for foliage yield per plot; Diwani (2015) for leaf area.

Table.1 Details of bathua genotypes used in study

\begin{tabular}{|c|c|c|}
\hline Sl. No. & Genotypes & Source \\
\hline 1 & EC-359444 & NBPGR, New Delhi \\
\hline 2 & NC-50229 & NBPGR, New Delhi \\
\hline 3 & HUB - 1 & Local collection from Chikkaballapur \\
\hline 4 & HUB - 2 & Local collection from Gouribidanur \\
\hline 5 & EC-359445 & NBPGR, New Delhi \\
\hline$\overline{6}$ & IC-243192 & NBPGR, New Delhi \\
\hline 7 & HUB - 3 & Local collection from Arabhavi-2 \\
\hline 8 & IC-341703 & NBPGR, New Delhi \\
\hline 9 & HUB - 4 & Local collection from Kondrapali \\
\hline 10 & IC-109249 & NBPGR, New Delhi \\
\hline 11 & NIC-22506 & NBPGR, New Delhi \\
\hline 12 & HUB -5 & Local collection from Palampalli \\
\hline 13 & NC-58616 & NBPGR, New Delhi \\
\hline 14 & NIC-22492 & NBPGR, New Delhi \\
\hline 15 & IC-109235 & NBPGR, New Delhi \\
\hline 16 & HUB-6 & Local collection from Kauvara \\
\hline 17 & HUB - 8 & Local collection from Arabhavi -1 \\
\hline 18 & IC-415477 & NBPGR, New Delhi \\
\hline 19 & IC-540831 & NBPGR, New Delhi \\
\hline 20 & NIC-22517 & NBPGR, New Delhi \\
\hline 21 & HUB - 7 & Local collection from Aruru \\
\hline 22 & IC-540842 & NBPGR, New Delhi \\
\hline 23 & IC-4152393 & NBPGR, New Delhi \\
\hline 24 & HUB - 9 & Local collection from Sangankeri \\
\hline
\end{tabular}


Table.2 Genotypic correlation coefficients among growth, yield and quality parameters in bathua

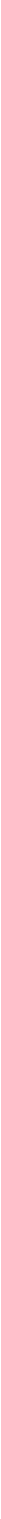


Number of branches per plant had found significant and positive association with leaf area, fresh weight of plant, dry weight of plant, foliage yield per plot, foliage yield per hectare, protein content, calcium content, iron content, zinc content, foliage yield per plant at both phenotypic and genotypic level. It indicates if more number of branches per plant it increases total foliage yield.

Leaf area is positively and significantly correlated with fresh weight, dry weight of plant, foliage yield per plot, foliage yield per hectare, vitamin-c content, protein content, calcium content, magnesium content, iron content, zinc content, foliage yield per plant at both phenotypic and genotypic level. It indicates if more leaf area it increases total foliage yield. Similar results were also obtained by Kujur (2015) for foliage yield per plot, dry weight of plant;

Positive and significant correlation was found for fresh weight of plant with dry weight of plant, foliage yield per plot, foliage yield per hectare, vitamin-A content, vitamin-C content, calcium content, magnesium content, iron content, zinc content, foliage yield per plant at both phenotypic and genotypic level. It indicates if more fresh weight of plant it increases total foliage yield. Positive and significant correlation was found for dry weight of plant with foliage yield per plot, foliage yield per hectare, vitamin-A, vitamin$\mathrm{C}$, protein content, calcium content, magnesium content, iron content, zinc content, foliage yield per plant. It indicates if more dry weight of plant it increases total foliage yield. Similar results were also obtained by Kujur (2015) for foliage yield per plot;

Positive and significant correlation was found for foliage yield per plot with foliage yield per hectare, vitamin-A, vitamin-c, protein content, calcium content, magnesium content, iron content, zinc content, and foliage yield per plant at both phenotypic and genotypic level. Similar results were also obtained by Kujur (2015) for foliage yield per plant.

Positive and significant correlation was found for foliage yield per hectare with vitamin-A, vitamin-C content, protein content, calcium content, magnesium content, iron content, zinc content, foliage yield per plant at both phenotypic and genotypic level. Vitamin A content had positive and significantly correlated with vitamin-C content, calcium content, magnesium content, zinc content, foliage yield per plant at both phenotypic and genotypic level. Vitamin $\mathrm{C}$ content had positive and significantly correlated with protein content, calcium content, magnesium content, iron content, zinc content, foliage yield per plant at both phenotypic and genotypic level.

Protein content had positive and significantly correlated with calcium content, magnesium content, iron content, zinc content, foliage yield per plant at both phenotypic and genotypic level. Calcium content had positive and significantly correlated with magnesium content, iron content, zinc content, foliage yield per plant at both phenotypic and genotypic level. Magnesium content had positive and significantly correlated with iron content, zinc content, foliage yield per plant at both phenotypic and genotypic level.

Iron content had positive and significantly correlated with zinc content, foliage yield per plant at both phenotypic and genotypic level. Zinc content had positive and significantly correlated with foliage yield per plant at both phenotypic and genotypic level.

From the foregoing discussions, it is conceivable that a great deal of success can be achieved in improvement of foliage yield per plant by applying selection pressure on plant 
height, number of leaves per plant, number of branches per plant, leaf area, stem girth, fresh weight of plant, dry weight of plant, foliage yield per plot, foliage yield per hectare as these traits had significant and positive correlation with foliage yield per plant.

\section{References}

Ahammed, A. U., Rahman, M. M. and Mian, M. A. K., 2012, Genetic variability, heritability and correlation in stem amaranthus (Amaranthus tricolor L.). Bangladesh J. Pl. Breed. Genet., 25 (2): 25-32.

Burton, G. W. and Devane, E. M., 1952, Estimating heritability in tall fescue (Festuca circunclinaceae) from replicated clonal material. Agron. J., 45: 478-481.

Diwan, I. S., 2015, Genetic studies in amaranthus (Amaranthus sp.) germplasm. M. Sc. Thesis, Indira Gandhi Krishi Vishwavidyalaya, Raipur.

Hassan, M., Akther, C. A. and Raihan, M. S., 2013, Genetic variability, correlation and path analysis in stem amaranthus
(Amaranthus tricolor L.) genotypes. The Agriculturist, 11 (1): 1-7.

Khurana, D. S., Sing. J. and Kaur, B., 2013, Genetic variability, correlation and path coefficient analysis in amaranthus. Vegetable Science, 40 (2): 238-240.

Kujur, A., 2015, Collection, Evaluation and identification of suitable genotypes of khedha (Amaranthus dubius Mart.) under Chhattisgarh plain condition. $M$. Sc. (Agri.) Thesis, Indira Gandhi Krishi Vishwavidyala, Raipur (Chhattisgarh).

Pandey, 2008. Underutilized vegetable crops. Satish Serial Publishing House, New Delhi, pp. 197-198.

Sanwal, S. K., 2008, Underutilized vegetable and spice crops. Agrobios, Jodhpur, 231-235p.

Sarker, U., Islam, T., Rabbani, G. and Oba, S., 2014, Genotypic variability for nutrient, antioxidant, yield and yield contributing traits in vegetable amaranthus. Journal of Food, Agriculture and Environment, 12 (3): 168-174.

Sivasubramanian, S. and Menon, M., 1973, Heterosis and inbreeding depression in rice. Madras Agric. J., 60: 1139.

\section{How to cite this article:}

Basavaraj, C.N. Hanchinamani, H.P. Hadimani, S.J. Imamsaheb, and Ramanagouda, S.H. 2018. Genotypic Correlation Coefficients among Growth, Yield and Quality Parameters in Bathua genotypes (Chenopodium album L.). Int.J.Curr.Microbiol.App.Sci. 7(08): 361-366. doi: https://doi.org/10.20546/ijcmas.2018.708.040 